University of Nebraska - Lincoln

DigitalCommons@University of Nebraska - Lincoln

2009

Feeding Ecology of Arctic-Nesting Sandpipers During Spring Migration Through the Prairie Pothole Region

Jan Eldridge

USGS Northern Prairie Wildlife Research Center

Gary Krapu

USGS Northern Prairie Wildlife Research Center, gkrapu@usgs.gov

Douglas Johnson

USGS Northern Prairie Wildlife Research Center, Douglas_H_Johnson@usgs.gov

Follow this and additional works at: https://digitalcommons.unl.edu/usgsnpwrc

Part of the Other International and Area Studies Commons

Eldridge, Jan; Krapu, Gary; and Johnson, Douglas, "Feeding Ecology of Arctic-Nesting Sandpipers During Spring Migration Through the Prairie Pothole Region" (2009). USGS Northern Prairie Wildlife Research Center. 56.

https://digitalcommons.unl.edu/usgsnpwrc/56

This Article is brought to you for free and open access by the US Geological Survey at DigitalCommons@University of Nebraska - Lincoln. It has been accepted for inclusion in USGS Northern Prairie Wildlife Research Center by an authorized administrator of DigitalCommons@University of Nebraska - Lincoln. 


\title{
Feeding Ecology of Arctic-Nesting Sandpipers During Spring Migration Through the Prairie Pothole Region
}

\author{
JAN L. ELDRIDGE, ${ }^{1,2}$ United States Geological Survey, Northern Prairie Wildlife Research Center, 8711 37th Street SE, Jamestown, ND 58401, USA \\ GARY L. KRAPU, United States Geological Survey, Northern Prairie Wildlife Research Center, 8711 37th Street SE, Jamestown, ND 58401, USA \\ DOUGLAS H. JOHNSON, United States Geological Survey, Northern Prairie Wildlife Research Center, 220 Hodson Hall, 1980 Folwell Avenue, Saint \\ Paul, MN 55108, USA
}

\begin{abstract}
We evaluated food habits of 4 species of spring-migrant calidrid sandpipers in the Prairie Pothole Region (PPR) of North Dakota. Sandpipers foraged in several wetland classes and fed primarily on aquatic dipterans, mostly larvae, and the midge family Chironomidae was the primary food eaten. Larger sandpiper species foraged in deeper water and took larger larvae than did smaller sandpipers. The diverse wetland habitats that migrant shorebirds use in the PPR suggest a landscape-level approach be applied to wetland conservation efforts. We recommend that managers use livestock grazing and other tools, where applicable, to keep shallow, freshwater wetlands from becoming choked with emergent vegetation limiting chironomid production and preventing shorebird use. (JOURNAL OF WILDLIFE MANAGEMENT 73(2):248-252; 2009)
\end{abstract}

DOI: $10.2193 / 2006-416$

KEY WORDS Calidris, Chironomidae, feeding ecology, midge larvae, North Dakota, sandpiper, shorebird.

In the Western Hemisphere, during spring, several species of sandpipers migrate from South America to Arctic regions in Canada and Alaska (Morrison 1984, Morrison and Myers 1989, Harrington 1999). The birds rely on a chain of stopovers that provide critical foraging habitats to fuel their long flights (Myers 1983, Myers et al. 1987). Stopovers include wetlands in the Prairie Pothole Region (PPR) of midcontinental North America, where many birds stop before continuing to their breeding grounds in northern Canada and Alaska (Skagen et al. 1999). During their spring stopovers in the PPR, some species of calidrid sandpipers develop large fat reserves, which contribute to energy needs for migration and nutrient requirements for reproduction (Krapu et al. 2006). Given the importance of the PPR for nutrient storage, detailed knowledge is needed of foods supplying nutrient requirements of sandpipers, characteristics of wetland habitats where the birds forage, and factors influencing food availability, so wildlife managers can implement effective strategies for meeting shorebird needs. Our objectives were to 1 ) identify foods consumed by pectoral sandpiper (Calidris melanotos), white-rumped sandpiper (Calidris fuscicollis), Baird's sandpiper (Calidris bairdii), and semipalmated sandpiper (Calidris pusilla) during spring stopovers in the PPR of eastern North Dakota during 1980 and 1981; and 2) compare wetland types among sites where the 4 species forage.

\section{STUDY AREA}

We conducted our study within a $5,000-\mathrm{km}^{2}$ area in Stutsman and Kidder counties of south-central North Dakota. The study area included parts of the Glaciated Plains and Missouri Coteau (described by Kantrud et al. 1989) and contained thousands of wetlands representing all

\footnotetext{
${ }^{1}$ E-mail: Jan@TheCoveStudio.com

2 Present address: Cove Studio, Inc. 246 Cove Lane, Hudson, WI 54016, USA
}

7 wetland classes identified by Stewart and Kantrud (1971) as occurring in the glaciated prairie region. Grazed uplands were more common in the western portion of the study area where soils and wetlands were more alkaline. In the eastern part, cropland dominated the watersheds of wetlands, and wetlands tended to be fresher and subject to higher levels of annual tillage (Kantrud et al. 1989).

The number of ponds on the study area fluctuated widely in response to differences in amounts of annual precipitation. The United States Fish and Wildlife Service estimated numbers of ponds (based on the annual May survey of breeding waterfowl and ponds in North America) in stratum 46 (which included our study area) as 89,437 in 1980 and 55,160 in 1981 (Smith 1995).

\section{METHODS}

We searched for sandpipers by driving 200-250 km each day from early April to June in 1980 and 1981 along arbitrarily selected routes throughout the study area. Searches encompassed the entire spring migration interval of the 4 species. Baird's sandpipers were the first of the 4 species to arrive, starting approximately 10 April, and white-rumped sandpipers were the last to depart, with most individuals leaving by approximately 15 June (Krapu et al. 2006). When we observed a flock containing $\geq 1$ of the 4 focal species foraging on a wetland, we attempted to shoot one foraging bird from each flock to determine foods taken. Following collection, we marked the site, tagged each specimen with a unique identification number, and immediately removed food items and placed them in labeled vials filled with alcohol to prevent digestion. At each site where we collected a sandpiper, we recorded wetland class following the classification system of Stewart and Kantrud (1971) to allow a comparison of wetland habitat use among the 4 species. To avoid pseudoreplication, we made comparisons of sandpiper use between wetland collection sites rather than 
Table 1. Wetland types used by foraging pectoral sandpiper, white-rumped sandpiper, Baird's sandpiper, and semipalmated sandpiper during spring stopovers (April 1980 to June 1881) in south-central North Dakota, USA. Distribution of sandpiper use by wetland class is expressed as the percentage that each wetland class represented of all wetland sites where we collected foraging sandpipers of a species (listed in parentheses).

\begin{tabular}{lcccc}
\hline & \multicolumn{3}{c}{ Species of shorebird } \\
\cline { 2 - 5 } \multicolumn{1}{c}{ Wetland class $^{\mathbf{a}}$} & $\begin{array}{c}\text { Pectoral sandpiper } \\
(\boldsymbol{n}=\mathbf{3 6})\end{array}$ & $\begin{array}{c}\text { White-rumped sandpiper } \\
(\boldsymbol{n}=\mathbf{8 6})\end{array}$ & $\begin{array}{c}\text { Baird's sandpiper } \\
(\boldsymbol{n}=\mathbf{8 0})\end{array}$ & $\begin{array}{c}\text { Semipalmated sandpiper } \\
(\boldsymbol{n}=\mathbf{8 2})\end{array}$ \\
\hline Class I-ephemeral & 0.0 & 0.0 & 1.3 & 0.0 \\
Class II-temporary & 0.0 & 0.0 & 0.0 & 1.2 \\
Class III-seasonal & 63.9 & 10.5 & 10.0 & 13.4 \\
Class IV-semipermanent & 27.8 & 37.2 & 17.5 & 24.4 \\
Class V-permanent & 0.0 & 9.3 & 57.5 & 11.0 \\
Class VI-alkali & 5.6 & 43.0 & 7.5 & 50.0 \\
Class VII-fen & 0.0 & 0.0 & 1.3 & 0.0 \\
Dugout & 2.8 & 0.0 & 0.0 \\
\hline
\end{tabular}

${ }^{a}$ Wetland classes I through VII follow wetland classification system of Stewart and Kantrud (1973) for wetlands in the glaciated prairie region.

among individuals because we collected $>1$ individual of a species at some sites. We also measured water depth and took a core sample from the substrate (Swanson 1978) at each site where we collected a sandpiper to compare macroinvertebrates consumed to those available. Upon our return to the laboratory, we measured tarsus and culmen length of each specimen to the nearest millimeter using a vernier caliper, and we weighed each bird to the nearest 0.1 $\mathrm{g}$ on a triple-beam balance. We took body measurements to compare species morphology with foraging depths and lengths of Diptera larvae consumed. Dietary analyses of esophageal contents followed Rundle (1982). We identified macroinvertebrates present in esophagi to family and measured length of each to the nearest $0.5 \mathrm{~mm}$. We calculated diet percentages using the aggregate percentage method (Swanson et al. 1974), averaging relative frequency of each food type in the esophagus across all individuals in the sample. As with esophageal samples, we identified to family each macroinvertebrate present in core samples, measured the length $(\mathrm{mm})$ of each, and stored them in alcohol. We compared macroinvertebrates in esophageal contents to macroinvertebrates available in core samples using the statistical ranking comparison of Johnson (1980) with PREFER, Resource Selection Software version 5.1 (Johnson 1980). We compared chironomid larval lengths from esophagus samples to chironomid larval lengths in the core samples taken at sites where we collected feeding individuals. If no selection for larval length was occurring, modal larval length would be most common in the substrate samples, with equal frequencies of those smaller or larger than modal length. We calculated the Pearson correlation coefficients between water depth and larvae size to determine whether those variables were related.

\section{RESULTS}

All 4 species of sandpipers foraged in several wetland classes during spring stopovers in North Dakota (Table 1). Pectoral sandpipers occurred primarily in seasonal wetlands, whereas the other 3 species occurred most often in alkali wetlands, followed by semipermanent and seasonal wetlands.

Diets of the 4 species of sandpipers overlapped broadly.
Arthropods accounted for $\geq 95 \%$ of foods taken by the 4 species (Table 2). The order Diptera formed $71-95 \%$ of the diets of the 4 species, with family Chironomidae accounting for $54-84 \%$ of foods consumed. Dipteran families Heleidae and Ephydridae accounted for $\geq 15 \%$ of the diets of $\geq 1$ species (Table 2). Crustacea formed $19 \%, 17 \%$, and $22 \%$ of diets of white-rumped, Baird's, and semipalmated sandpipers, respectively, but $<1 \%$ of the diet of pectoral sandpipers (Table 2).

Table 2. Aggregate percent frequency of food types removed from esophagi of pectoral sandpipers, white-rumped sandpipers, Baird's sandpipers, and semipalmated sandpipers collected while feeding in prairie wetlands in south-central North Dakota, USA, during the spring of 1980 and 1981. Each bird in the sample $(n)$ represents an individual having $\geq 1$ food items in its esophagus.

\begin{tabular}{|c|c|c|c|c|}
\hline Species & $\begin{array}{l}\text { Pectoral } \\
\text { sandpiper }\end{array}$ & $\begin{array}{l}\text { White-rumped } \\
\text { sandpiper }\end{array}$ & $\begin{array}{l}\text { Baird's } \\
\text { sandpiper }\end{array}$ & $\begin{array}{l}\text { Semipalmated } \\
\text { sandpiper }\end{array}$ \\
\hline$n$ & 42 & 94 & 81 & 100 \\
\hline Annelida & 2.3 & 0.0 & 0.0 & 0.0 \\
\hline Mollusca & 0.0 & 0.0 & 0.4 & 2.0 \\
\hline Arthropoda & 95.2 & 97.7 & 99.6 & 96.7 \\
\hline Oligochaeta & 1.2 & 0.0 & 0.0 & 0.0 \\
\hline Hirundinea & 1.2 & 0.0 & 0.0 & 0.0 \\
\hline Crustacea & 0.8 & 19.4 & 17.0 & 21.7 \\
\hline Eubranchiopoda & 0.0 & 1.1 & 9.7 & 1.0 \\
\hline Cladocera & 0.5 & 14.1 & 0.6 & 12.2 \\
\hline Copepoda & 0.0 & 3.2 & 1.3 & 8.3 \\
\hline Ostracoda & 0.0 & 1.1 & 0.0 & 0.5 \\
\hline Amphipoda & 0.3 & 0.0 & 5.4 & 0.5 \\
\hline Insecta & 96.7 & 80.9 & 88.9 & 78.0 \\
\hline Emphemeroptera & 2.0 & 0.0 & 0.0 & 0.1 \\
\hline Odonota & 0.0 & 0.5 & 0.0 & 0.8 \\
\hline Hemiptera & 0.0 & 0.3 & 3.5 & 3.5 \\
\hline Coleoptera & 2.5 & 1.3 & 2.5 & 1.8 \\
\hline Diptera & 94.6 & 78.4 & 77.1 & 71.3 \\
\hline Chironomidae & 83.5 & 54.0 & 73.0 & 60.8 \\
\hline Heleidae & 2.0 & 19.0 & 16.4 & 16.4 \\
\hline Ephydridae & 11.2 & 20.1 & 7.6 & 11.2 \\
\hline Anthomyiidae & 0.0 & 2.6 & 9.4 & 0.4 \\
\hline Cyclorrhapha & 0.0 & 4.3 & 2.7 & 8.1 \\
\hline Tabanidae & 0.8 & 0.0 & 0.0 & 0.0 \\
\hline Stratiomyidae & 2.4 & 0.0 & 0.0 & 0.0 \\
\hline Gastropoda & 0.0 & 0.0 & 0.4 & 2.0 \\
\hline Arachnida & 0.0 & 0.0 & 1.3 & 0.3 \\
\hline Plant matter & 2.4 & 2.3 & 0.0 & 1.3 \\
\hline
\end{tabular}


Table 3. Aggregate percentage frequency of Diptera larva, pupa, and adults in esophagi and associated core samples of pectoral sandpipers, whiterumped sandpipers, Baird's sandpipers, and semipalmated sandpipers collected while feeding in prairie wetlands in south-central North Dakota, USA, during the spring of 1980 and 1981. Each bird in the sample represents an individual having $\geq 1$ food items in its esophagus.

\begin{tabular}{lllcc}
\hline \multicolumn{1}{c}{ Species } & $\boldsymbol{n}$ & Stage & $\begin{array}{c}\text { \% in } \\
\text { esophagus }\end{array}$ & $\begin{array}{c}\text { \% in core } \\
\text { sample }\end{array}$ \\
\hline Pectoral sandpiper & \multirow{2}{*}{29} & Larva & 83.4 & 85.8 \\
& & Pupa & 17.6 & 11.3 \\
& & Ad & & 2.8 \\
White-rumped sandpiper & \multirow{2}{*}{46} & Larva & 78.4 & 79.6 \\
& & Pupa & 21.6 & 14.6 \\
Baird's sandpiper & & Ad & & 5.8 \\
& \multirow{2}{*}{42} & Larva & 78.2 & 81.8 \\
Semipalmated sandpiper & \multirow{2}{*}{38 Pupa } & 19.4 & 12.4 \\
& & Ad & 2.4 & 5.9 \\
& & Larva & 81.1 & 80.5 \\
& & Pupa & 18.9 & 14.2 \\
& & Ad & & 5.2 \\
\hline
\end{tabular}

When we paired esophagus and substrate samples for individual birds, we found Diptera were most common in both sample types. Percentages of paired samples in which both substrate and esophagus samples contained Chironomidae were $92 \%$ for pectoral sandpipers $(n=28), 72.2 \%$ for semipalmated sandpipers $(n=47), 69.8 \%$ for Baird's sandpipers $(n=43)$, and $68.9 \%$ for white-rumped sandpipers $(n=45)$.

Approximately $80 \%$ of Diptera consumed by the 4 species were in the larval stage, which was proportional to their availability in core samples (Table 3). Pupae accounted for all remaining Diptera consumed by pectoral, white-rumped, and semipalmated sandpipers. Pupae were present in greater frequency (1.33-1.56 times greater) in esophageal contents of all 4 species than in core samples (Table 3 ), but preference for pupae was significant $(P<0.05)$ only in Baird's sandpiper. Given a choice, sandpipers tended to select the larger chironomid larvae available to them in the substrate; all 4 species, especially white-rumped and semipalmated sandpipers, consumed larvae that were longer than the modal length: $41-69 \%$ were larger than modal size versus $21-35 \%$ that were smaller than modal length (Table 4).

Larger-bodied sandpiper species consumed larger chironomid larvae (body mass and larvae length: $r=0.92, P=$ $0.076, n=4$ species) and had greater variation in water levels where the individuals foraged (body mass and SD of water depth: $r=0.976, P=0.024, n=4$ species; Table 5), reflecting their greater reach. Among Baird's, whiterumped, and semipalmated sandpipers that foraged in mixed-species flocks, there was a trend toward larger species foraging in deeper waters where chironomid larvae were larger ( $r=0.34, P=0.003, n=74$ wetlands; Fig. 1).

\section{DISCUSSION}

Chironomid larvae dominated the diets of the 4 species of sandpipers in the diverse wetland habitats used during their spring stopovers in North Dakota, which is consistent with Chironomidae being among the most abundant and widely
Table 4. Percentage of chironomid larva consumed by 4 sandpiper species collected while feeding in prairie wetlands in south-central North Dakota, USA, during the spring of 1980 and 1981, that were larger, the same, or smaller in size than the modal size available. We determined availability from a core sample taken at the site where a collected bird had been foraging. Size of chironomid prey is length, measured to the nearest millimeter.

\begin{tabular}{lllll}
\hline & & \multicolumn{2}{c}{ Size of larval prey (mm) } \\
\cline { 3 - 5 } \multicolumn{1}{c}{ Species } & $\boldsymbol{n}$ & Smaller & Same & Larger \\
\hline Pectoral sandpiper & 23 & 34.8 & 13.8 & 52.5 \\
White-rumped sandpiper & 29 & 24.1 & 6.9 & 69.0 \\
Semipalmated sandpiper & 24 & 20.8 & 12.5 & 66.7 \\
Baird's sandpiper & 29 & 34.5 & 24.1 & 41.4 \\
\hline
\end{tabular}

distributed invertebrate group in prairie wetlands (Wrubleski 1987). Wide distribution of chironomids indicates that they are among the few invertebrate species capable of surviving a wide range of temperatures, drying, high salinity, and low oxygen (Oliver 1971, Driver 1977, Wiggins et al. 1980). Midges most commonly taken by sandpipers were of the subfamily Chironominae and usually of the genus Chironomus. Larvae in Chironominae contain hemoglobin, which allows them to survive under low oxygen levels that are common in shallow prairie ponds with receding water levels, a key shorebird foraging habitat. The exceptional importance of chironomids to meeting sandpiper nutrient requirements results, in part, because numbers of larvae can quickly build in response to the nutrient flush from decomposing vegetation caused by annual water cycles (Driver 1977, Murkin and Batt 1987, Nelson 1989). Chironomid larvae are most abundant in areas of shallow, open water, where shading is minimal (Wiggins et al. 1980, Nelson 1989).

During spring migration, Arctic-nesting sandpipers meet their dietary needs by foraging on thousands of widely distributed wetlands in the PPR. We rarely saw large concentrations of migrant sandpipers on any single wetland. The lack of large concentrations of birds presumably resulted, in part, because few wetlands had large expanses of water at depths suitable for foraging, and chironomid larvae usually were distributed in patches of limited area. Alkali ponds and lakes, a major foraging habitat of 3 of the 4 species we studied, contain high salt concentrations in most years, limiting plant growth and providing wide areas potentially suitable for foraging. Alkali ponds and lakes normally have freshwater springs (Stewart and Kantrud 1971), which allow many of these basins to hold some water during all but the most severe droughts. As a result, alkali wetlands are likely to be most important in meeting nutrient needs of migrant shorebirds during periods when freshwater ponds are mostly dry or altered in ways that discourage shorebird use.

Peak spring migration for most Arctic-nesting sandpipers in the PPR occurs during May (Skagen et al. 1999, Krapu et al. 2006), which corresponds with peak abundance of chironomid larvae in prairie potholes in North Dakota (Nelson 1989). Our observations fit the stepping-stone 
Table 5. Pectoral sandpiper, white-rumped sandpiper, Baird's sandpiper, and semipalmated sandpiper body masses, tarsus lengths, and culmen lengths, compared with foraging water depths and lengths (mm) of chironomid larvae consumed, during the spring of 1980 and 1981 in south-central North Dakota, USA. We included only foraging sandpipers collected with Chironomidae larvae in their esophagi in the analysis.

\begin{tabular}{|c|c|c|c|c|c|c|c|c|c|c|c|}
\hline \multirow[b]{3}{*}{ Species } & \multirow[b]{3}{*}{$n$} & \multicolumn{6}{|c|}{ Sandpiper measurements } & & & & \\
\hline & & \multicolumn{2}{|c|}{ Body mass (g) } & \multicolumn{2}{|c|}{ Tarsus length (mm) } & \multicolumn{2}{|c|}{ Culmen length $(\mathrm{mm})$} & \multicolumn{2}{|c|}{ Water depth (mm) } & \multicolumn{2}{|c|}{ Larvae length $(\mathrm{mm})$} \\
\hline & & $\bar{x}$ & SD & $\bar{x}$ & SD & $\bar{x}$ & SD & $\bar{x}$ & SD & $\bar{x}$ & SD \\
\hline Pectoral sandpiper & 32 & 76.1 & 13.0 & 28.8 & 1.6 & 28.2 & 1.3 & 22.6 & 17.8 & 10.0 & 5.2 \\
\hline White-rumped sandpiper & 39 & 45.0 & 5.3 & 25.4 & 1.0 & 23.6 & 1.1 & 26.8 & 15.3 & 7.6 & 4.3 \\
\hline Baird's sandpiper & 33 & 41.9 & 3.7 & 23.4 & 1.3 & 23.1 & 1.3 & 15.6 & 12.2 & 6.9 & 3.8 \\
\hline Semipalmated sandpiper & 43 & 30.2 & 4.1 & 22.6 & 1.0 & 19.2 & 1.4 & 13.7 & 10.6 & 6.8 & 3.8 \\
\hline
\end{tabular}

model of Harrington (1999) and Bottom et al. (1994), who described a global cycle of sandpiper movement timed to coincide with superabundant flushes of food. In this respect, the function of the PPR to sandpipers is analogous to a large, coastal estuary, such as Delaware Bay, where migrating sandpipers move within a larger estuary to find specific, locally abundant food patches (Bottom et al. 1994). In the northern plains, considering the diverse wetland types that migrant sandpipers rely upon to meet their dietary requirements and the marked annual variation in distribution of wet ponds suitable for shorebird use, it is critical that a diverse range of wetland types remain widely distributed across the region.

\section{Management Implications}

Because chironomid larvae are the principal food of migrant sandpipers in the PPR, as well as a major food of female prairie-nesting ducks during reproduction (Krapu and Reinecke 1992), we suggest that wetland managers in the PPR consider ways of increasing chironomid production in prairie wetlands, by creating openings in shallow wetlands

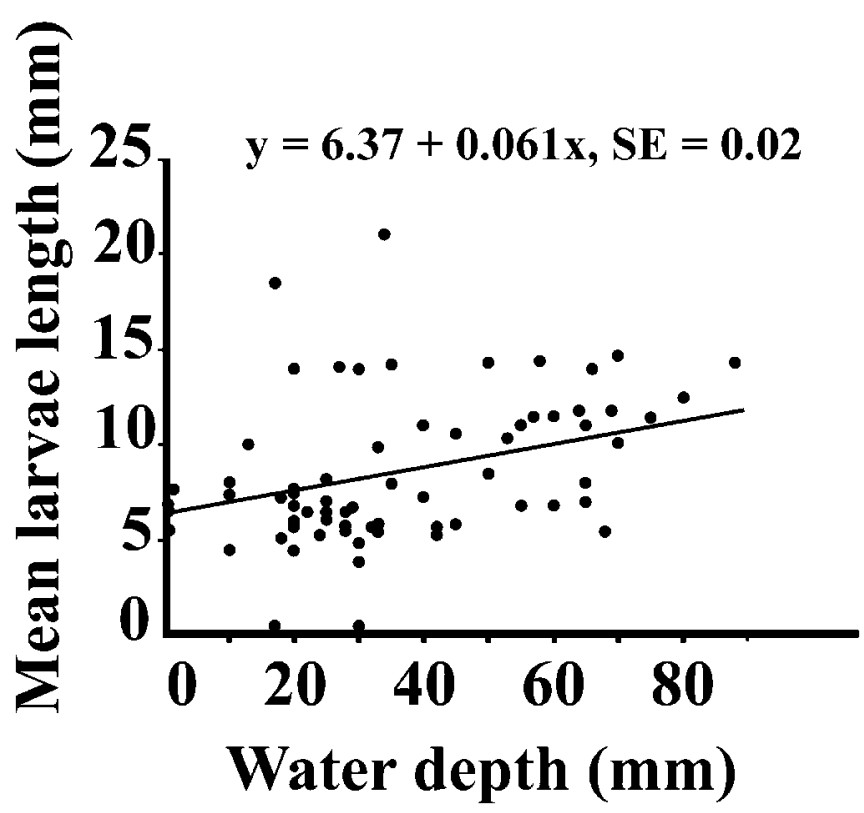

Figure 1. Mean Chironomidae larvae length (closed circles) in relation to foraging water depth (averaged by core sample) at sites on 74 prairie wetlands where arctic-nesting sandpipers foraged in south-central North Dakota, USA, April 1980 to June 1981. having closed canopies of cattail (Typha spp.) and other emergent aquatic vegetation that limit chironomid production and discourage use by shorebirds and waterfowl. With a major part of the privately owned shallow wetland habitat in the PPR being tilled and cropped when dry, reducing its value to water birds when wet, research is needed to develop economically viable farming practices that will increase the capacity of cropped basins to produce chironomids and other macroinvertebrate foods. For alkali ponds and lakes, the primary management need is to maintain historic levels of groundwater discharge from seeps and freshwater springs, particularly during drought, when most other basins are dry.

\section{Acknowledgments}

Field research was funded by the United States Fish and Wildlife Service through the Northern Prairie Wildlife Research Center. We are grateful to R. Atkins, M. Meyers, M. Rabenberg, and C. Shaiffer for assisting in data collection and to numerous landowners who allowed access to their properties. We also thank D. A. Brandt for assistance in data preparation and R. R. Cox, Jr.; C. S. Errington; C. L. Gratto-Trevor; and J. A. Shaffer for reviewing and commenting on earlier drafts of the manuscript.

\section{LITERATURE CITED}

Bottom, M. L., R. E. Loveland, and T. R. Jacobsen. 1994. Site selection by migratory shorebirds in Delaware Bay and its relationship to beach characteristics and abundance of horseshoe crab (Limulus polyphemus) eggs. Auk 111:605-616.

Driver, E. A. 1977. Chironomid communities in small prairie ponds: some characteristics and controls. Freshwater Biology 7:121-133.

Harrington, B. 1999. The hemispheric globetrotting of the white-rumped sandpiper. Pages 119-133 in K. P. Able, editor. Gathering of angels: migrating birds and their ecology. Cornell University, Ithaca, New York, USA.

Johnson, D. H. 1980. The comparison of usage and availability measurements for evaluating resource preference. Ecology 61:65-71.

Kantrud, H. A., G. L. Krapu, and G. A. Swanson. 1989. Prairie basin wetlands of the Dakotas: a community profile. U.S. Fish and Wildlife Service Biological Report 85(7.28), Washington, D.C., USA.

Krapu, G. L., J. L. Eldridge, C. L. Gratto-Trevor, and D. A. Buhl. 2006. Fat dynamics of Arctic-nesting sandpipers during spring in midcontinental North America. Auk 123:323-334.

Krapu, G. L., and K. J. Reinecke. 1992. Foraging ecology and nutrition. Pages 1-29 in B. D. J. Batt, A. D. Afton, M. G. Anderson, C. D. Ankney, D. H. Johnson, J. A. Kadlec, and G. L. Krapu, editors. Ecology and management of breeding waterfowl. University of Minnesota, Minneapolis, USA. 
Morrison, R. I. G. 1984. Migration systems of some New World shorebirds. Pages 125-202 in J. Burger and B. L. Olla, editors. Shorebirds: migration and foraging behavior. Plenum, New York, New York, USA.

Morrison, R. I. G., and J. P. Myers. 1989. Shorebird flyways in the New World. Pages 85-96 in H. Boyd and J. Y. Pirot, editors. Flyways and reserve networks for water birds. International Waterfowl and Wetlands Research Bureau Special Publication 9, Slimbridge, Gloucester, United Kingdom.

Murkin, H. R., and B. D. J. Batt. 1987. The interactions of vertebrates and invertebrates in peatlands and marshes. Memoirs of the Entomology Society of Canada 140:15-30.

Myers, J. P. 1983. Conservation of migrating shorebirds: staging areas, geographic bottlenecks, and regional movements. American Birds 37:2325.

Myers, J. P., R. I. G. Morrison, P. Z. Antas, B. A. Harrington, T. E. Lovejoy, M. Sallaberry, S. E. Senner, and A. Tarak. 1987. Conservation strategy for migratory species. American Scientist 75:18-26.

Nelson, R. D. 1989. Seasonal abundance and life cycles of chironomids (Diptera: Chironomidae) in four prairie wetlands. Dissertation, North Dakota State University, Fargo, USA.

Oliver, D. R. 1971. Life history of the Chironomidae. Annual Review of Entomology 16:211-230.

Rundle, W. D. 1982. A case for esophageal analysis in shorebird food studies. Journal of Field Ornithology 53:249-257.

Skagen, S. K., P. B. Sharpe, R. G. Waltermire, and M. B. Dillon. 1999.
Biogeographical profiles of shorebird migration in midcontinental North America. U.S. Geological Survey, Biological Science Report USGS/ BRD/BSR-2000-0003, Fort Collins, Colorado, USA.

Smith, G. W. 1995. A critical review of the aerial and ground surveys of breeding waterfowl in North America. National Biological Service Biological Science Report 5, Washington, D.C., USA.

Stewart, R. E., and H. A. Kantrud. 1971. Classification of natural ponds and lakes in the glaciated prairie region. U.S. Fish and Wildlife Service Resource Publication 92, Washington, D.C., USA.

Swanson, G. A. 1978. A simple lightweight core sampler for quantitating waterfowl foods. Journal of Wildlife Management 42:426-428.

Swanson, G. A., G. L. Krapu, J. C. Bartonek, J. R. Serie, and D. H. Johnson. 1974. Advantages in mathematically weighting waterfowl food habits data. Journal of Wildlife Management 38:302-307.

Wiggins, G. B., R. J. Mackay, and I. M. Smith. 1980. Evolutionary and ecological strategies of animals in annual temporary pools. Archiv für Hydrobiologie Supplement 58:97-206.

Wrubleski, D. A. 1989. The effect of waterfowl feeding on a chironomid (Diptera: Chironomidae) community. Pages 691-696 in R. R. Sharitz and J. W. Gibbons, editors. Freshwater wetlands and wildlife: perspectives on natural, managed and degraded ecosystems. CONF8603101. United States Department of Energy (USDOE) Symposium, USDOE, Office of Scientific and Technical Information Series 61, Oak Ridge, Tennessee, USA.

Associate Editor: Chamberlain. 